\title{
Cultural Survival, Continuance and the Oral Tradition: Mendu Theatre of the Riau Islands Province, Indonesia
}

\section{Karen Kartomi Thomas}

Research Fellow Performing Arts Academy Monash University, 3800

email: karen.thomas@monash.edu

\begin{abstract}
This article seeks to describe Mendu theatre that is performed in Sedanau, Natuna regency (kabupaten) of one of Indonesia's newest provinces, the Riau Island. ${ }^{1}$ Once popular at the turn of the $20^{\text {th }}$ century and in the 1970 s and 1980s, there were local Mendu groups in every village of Natuna in parts of northern and eastern Bunguran island, and other smaller islands such as Sedanau, Pulau Tiga, Karempak, Midai, Siantan, and Anambas (K.S. Kartomi 1986; Illyassabli, 2013; Akib 2014). The oral tradition keeps a people's culture alive across generations by performing episodes from memory. Mendu theatre episodes express and reinstate the cultural values of the Natuna people. Language, culture, customary laws and how the people think are transmitted orally through the arts and through the embodied knowledge of theatre performance practices.
\end{abstract}

Keywords: mendu theatre, oral tradition, cultural survival

\section{INTRODUCTION}

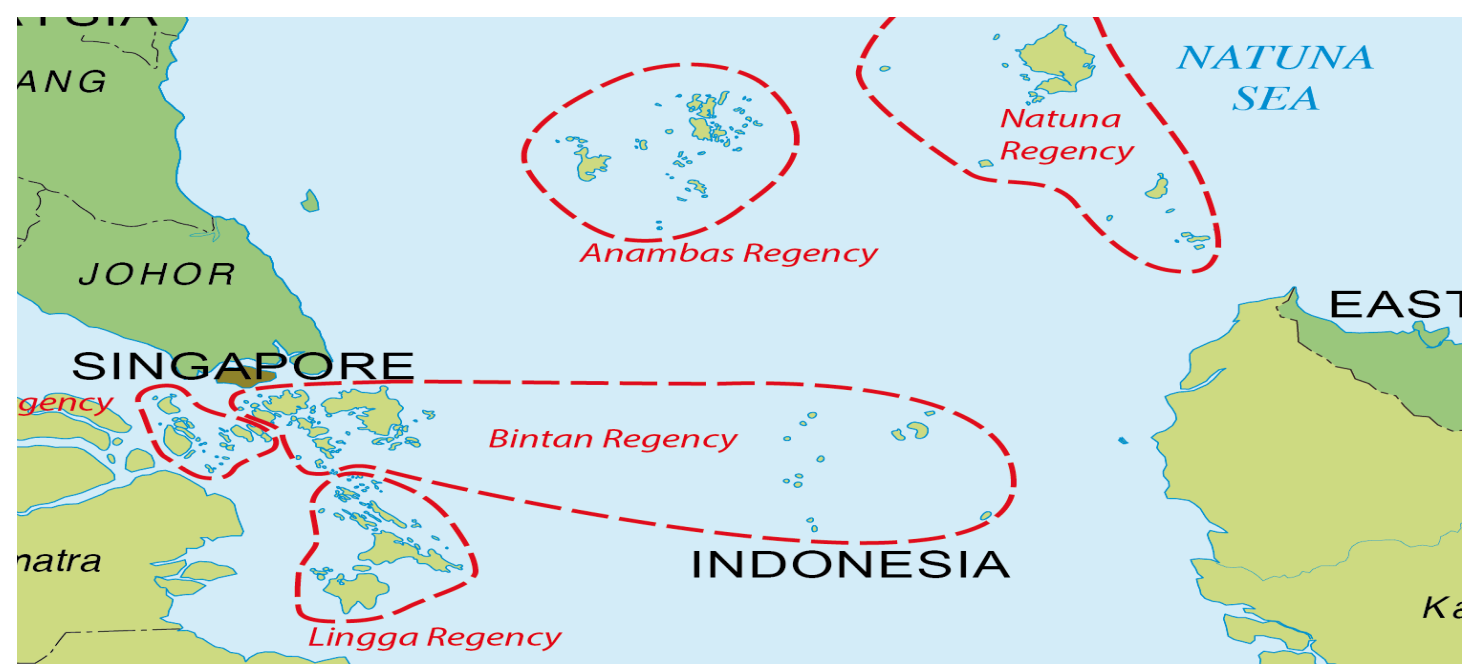

Figure 1 here. CAPTION: Map of Riau Islands' Province (Kepulauan Riau) and it's five regencies (kabupaten), Natuna, Anambas, Lingga, Bintan and Karimun.

1 I am grateful to the director of Semadun Dewa Mendu Almarhum Bp. Ahmadiah Zalman, the lead female actor Kak Uchy Sulfarini, and the lead male actor and group's manager Bp Sukardan for the information they generously imparted to me and for allowing me to record a Mendutheatre performance during my visit to Sedanau, Natuna Regency in 2013. And also Professor Margaret Kartomi, my mother and research companion, who made this research possible and enjoyable. 
Natuna regency, an archipelago in the northern most tip of Indonesia among the Riau Islands, was once part of the centuries-old maritime route between China and India via the Malacca straits, with numerous shipwrecks found in the area. These shipwrecks were found to contain old artifacts such as Chinese ceramics and other crockery, weapons including kris and metal spears, metal coins, and musical instruments such as gongs. Manyhistorical artifacts are now stored and displayed in the Sri Serindit Museum in Ranai, with new items frequently being unearthed by locals even today.

The Riau Islands' province broke away from Riau mainland in Sumatra just 10 years ago gaining its independence only in 2004. Since then the province's local governments have embarked on a quest not only to rebuild their communities through improved infrastructure, education, and address crime and other social issues, but also to revitalize their arts in order to claim and frame their cultural identity (Drs H. Daria 2014).

This article focuses on theatre practitioner and director, Bp Ahmadiah whom I met in January 2013, and his efforts in revitalising Mendu theatre. The local government of Natuna has identified and nominated Mendu theatre as one of its distinct cultural symbols that represents the regency and itsculture to the outside world (Illyassabli 2013). This led Bp Ahmadiah's Semadun DewaMendu group to compose and produce a contemporary version of Mendu theatre in the last decade with a regional and national audience in mind.

In the past, the Mendu legend of Dewa Menduwas performed at life-stage celebrations such as weddings and communal healing ceremonies, often at allnight performances for days on end. Traditional performances up to the late 1980s lasted 4-8 hours finishing after midnight or in the early hours of the morning. Once popular at the turn of the $20^{\text {th }}$ century and in the 1970s and 1980s, Mendu theatre was performed in Bunguran, Sedanau, Pulau Tiga, and Siantan of the Natuna islands (Karen S. Kartomi 1986). A related form of Mendu developed independently in the West Kalimantan regency of Mempawah, about 70km north of Pontianak, at least since the early 1900s (see Skeat 1967, p. 520), which has seen a modest revival since the 1970s (Sataruddin 2014).

The Mendu story as performed in Natuna is about a hero known as Dewa Mendu, a Panji-like Malay hero and his adventures with his brother Angkaran Dewa on earth. The two brothers are confronted by challenge after challenge either in physical battle or mystical contest after being thrown into one of the earth's deep seas by the gods from above. The story tells of their many extended journeys, and also of their descendants who, after traversing the earth far and wide and ensuring prosperity among the mythical lands they rule as Malay sultans, they finally leave the human world and return to the land of the gods.

As a contemporary expression of an old theatre practice, in its reinvention Mendu provides a space in which to re-examine and reimagine accepted Malay ancestry, and to reemphasize Malay cultural survival, identity and continuance. Rootedin a long-standing oral performing art form, contemporary Mendu is a 
new iteration of the oral tradition, a reinvention that sets out a space in which to retell, reanimate, and vocalize accepted stories to reassert its nature and connect with the contemporary audience. Mendu theatre is only fully realized in live performance. Each performance sheds light on views on relationships (1) of the present to the past Malay heritage, (2) between the living and the dead, and (3) between social disparities and the people's moral world. Materials received from the past are repeated, elaborated, condensed, extended and expanded or deleted entirely, all at the performers' whim (see further Drewal in Fiebach 2002: 27). The oral tradition keeps a people's culture alive across generations by performing episodes from memory, which express and reinstate the people's values through theatre practices. One of the significant ways the language, culture, customary laws and how the people think is transmitted orally through the arts and through the embodied knowledge of theatre performance practices.

I have written elsewhere about the traditional practices and techniques of Mendu that I recorded in Ranai, the capital of Natuna 30 years ago in 1984 (Karen S. Kartomi 1986). There I examine the structures of plot development, charactertypes that are established through stylized language and informal dialogue, movement, dance and music, the use of rhythm, alliteration and rhyme of kernel phrases, sentences and song-texts, dance, movement and melody. I also briefly discuss the role of the director (kalipah) who not only directs the action on stage but also, in his capacity as a healer (dukun), calls upon the spirits to enter the stage area and enlist their assistance for the success of the performance (Syafaruddin 2002).

I further discuss some of the motifs and themes in conjunction with the role of music that characterize the traditional form and that are essential methods employed by performers to generate each production.Performers draw on all of these elements performatively, that is, they are stored in memory, and recalled orally in the moment of subsequent transmission in performance (see further Rosenberg 1987: 80). No scripts or texts are written or used. Formal rehearsals as a whole production are therefore minimal and infrequent. Actors' improvisational techniques employ the network of traditional linguistic, movement and musical motifs, which are transmitted orally in performance for generations, and which are familiar to local, community audiences. The slow moving action is traditionally embellished by elaborate and extended items of dance and music, with frequent interspersions of comedy. Actors who generate the Mendu style of oral, embodied discourse assume character-types - such as Dewa Mendu, Siti Mahdewi, Raja Langkadura and the villain Raja Laksemalik - that tend to be noticeably stark, memorable and monumental rather than three-dimensional (see further Ong 1982: 34-40; 152).

In addition, masks are worn by clown-type characters such as the villain's jin assistant, Nenek Kebandan (Bakar 200?). Masks deliberately distort the physical appearance of the face. They are characterized by somewhat more threedimensional elements than the stark or monumental of the heroes, and form one 
of the primary sources of the theatre's aesthetic. During the course of the event, the director introduces clown figures when he notices audience attention waning in order to inject humor and energy back into the performance (Ahmadyiah, 2013).

The term "oral tradition" refers to the transmission of "...cultural items from one member to another, or others" specifically in face-to-face contact (Goody and Watt in Goody 1968: 58-59). I take this definition further to include not only face-toface, verbal contact but contact that consumes the whole body, a definition that incorporates the kinesthetic and the rhythmic both in sound and movement. The production of Mendu theatre is a living example of the culture's oral discourse as being, among other things, slow moving, additive, frequently redundant, and as relying on mnemonic patterns in language, music, dance and gesture.

The contemporary theatre continues to draw its inspiration from local beliefs, customs, ritual, stories and history that make up the region's rich oral repository. No scripts or texts are used. The creation of the theatre in the performative moment continues to rely on oral composition and its many hallmarks such as repetition, redundancy, additive and mnemonic pattern in language, dance and music motifs, the craft of which is transmitted orally from one generation to the next. Scenes in contemporary performance progress in ways that are reminiscent of traditional Mendu performances.. Traditional conventions have re-appropriated into contemporary Mendu. One of these reappropriations is the typical stage formation of court scenes in which the king stands or sits behind a table facing his three ministers, the perdana menteri, the wazier and the pahlawan (figure 1). Another is the use of codified acting and gestures such as those performed in scenes in which members of the nobility communicate with one another by holding a fan in the right hand, singing verses, and performing gestures in mirror image of one another or in unison (figure 2).

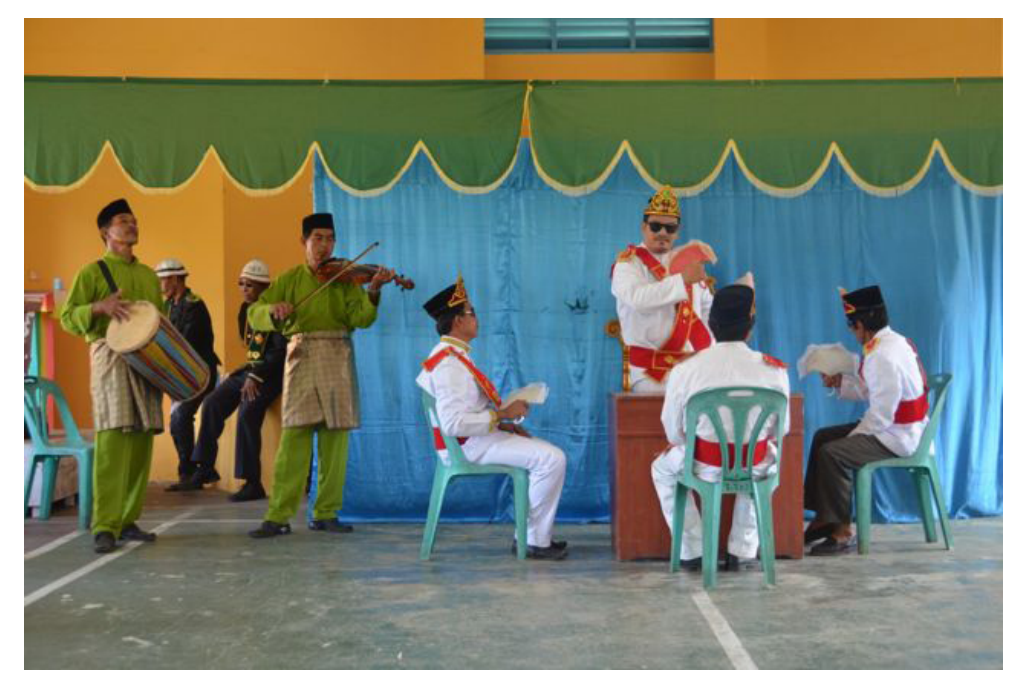

Figure 1 Here (DSC_0267). CAPTION: Raja Langkadura meets with his three ministers, the perdana menteri, the wazier and the pahlawan. Accompanied by biola, gendang panjang player and gong. 


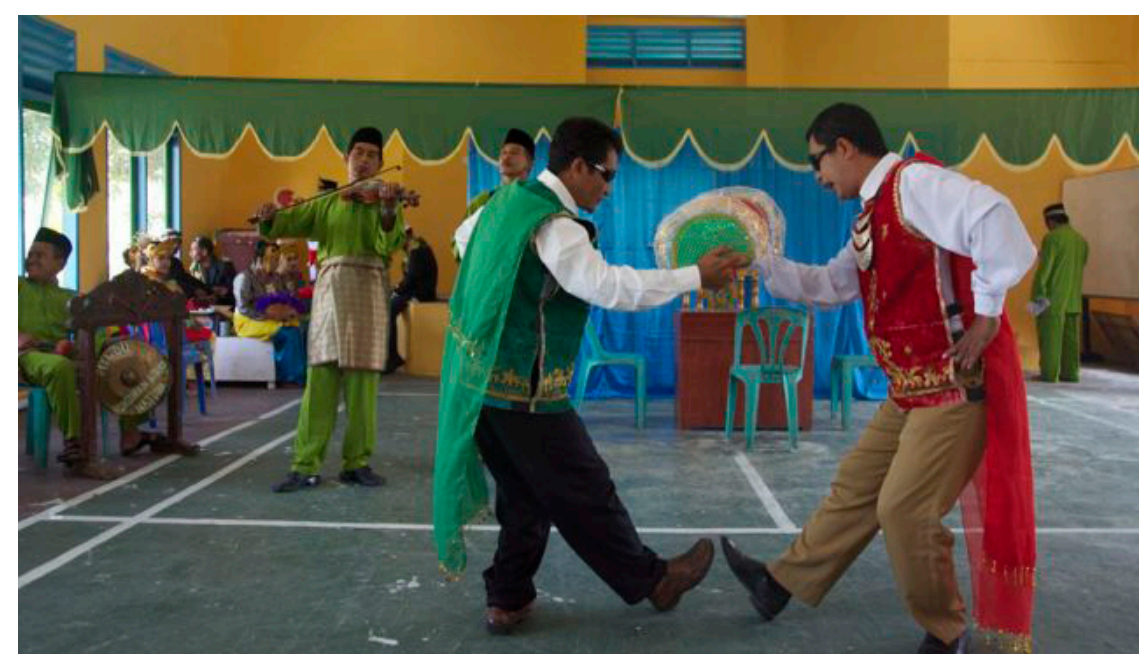

Figure 2 Here (DSC_0331DM). CAPTION: Dewa Mendu (right) and brother Angakaran Dewa perform gestures of communication with fans in hand between people of noble rank. Sedanau, Natuna Regency, 2013.

Combining the music, song, movementand dialogue is integral to the narrative, aiming to stir the emotions of the listeners and to close the distance (or break the barrier) between the narrative and the audience. The audience expects the verbal to convey the conventions accurately but in an improvised manner, yet members of the audience do not necessarily pay attention to every word.Language, dialogue, speech, words are not paramount (as in modern theatre built on the Aristotelian tradition) but of equal importance to the music, song, dance, gesture, and plot of the production as a whole. Mendu theatre is more than simply the coming together of visual and aural components. The attraction of the audience depends on the possession of charming voices equal to an ability to narrate and move the plot along through dialogue within the confines of the conventions, both linguistically and kinesthetically. It is the balance of many components as a whole - the gestures, the music, the words, the individual charm of the actors - that give rise to the production of one of the theatre's most important Malay-Indonesian conventions, that of pesona (charming, magnetic quality).A performance is an allbody, experiential, bodily event critical to creating pesona or that particular space in which a physical relationship with the onlookers is grippingly formed (see further Thomas 2013: 392).

\section{CONCLUSION}

The oral tradition keeps a people's culture alive across generations by performing episodes live from memory, episodes which express and reinstate the people's values. The language, culture, customary laws and people's thinking processes are transmitted orally through the arts and through the embodied knowledge of theatre performance practices. The oral tradition ensures both cultural survival across generations by performing episodes from memory, and also continuance of an old theatre form that carries with it a distinct Malay-Indonesian heritage. In the case of Mendu, Bp Ahmadiah responded to the local Natuna's government's 
invitation to indigenous artists to assist in revitalizing the region's performing arts. His re-appropriation of indigenous Mendu theatre conventions in recent years brought about a re-imagination of an ancestry and identity in a performing art form, which has reinvented not only a space in which to animate and vocalize the Mendu story but has cultural survival and continuance as well as forged new connections with changed, contemporary audiences.

\section{REFERENCES}

Ahmadiah Zulman, Almarhum Bp. 2013. Personal communication, Sedanau, Natuna, Riau Islands, January

Daria, Drs. H. (Bupati Lingga, Riau Islands Province), 2014. Personal communication, Daik-Lingga, Riau Islands, June

Fiebach, Joachim. 2002. “Theatricality: From Oral Traditions to Televised 'Realities,' SubStance, Vol. 31, No. 2/3, Issue 98/99, pp. 17-41

Goody, Jack (ed). 1968. Literacy in Traditional Societies. Cambridge: Cambridge University Press.

Illyassabli, Drs H. (Bupati Natuna, Riau Islands Province). 2013. Personal communication, Ranai Bungguran, Natuna, Riau Islands, January.

Kartomi, Karen Sri. "Mendu Theatre on the Island of Bunguran, Natuna, Indonesian" BA Honours thesis 1986, Monash University.

Ong, Walter J. 1982. Orality and Literacy. New York: Methuen

Rosenberg, Bruce. A 1987. “The Complexity of Oral Tradition.” Oral Tradition, Vol 2, No 1, p73-90

Sataruddin. Ramli. Bp. 2014. Personal communication, Pontianak, West Kalimantan, September.

Syafaruddin. Bp. "Tinjauan Bentuk Penyajian Kesenian Mendu di Sedanau, Kecamatan Bunguran Barat, Kabupaten Natuna, Propinsi Riau." BA thesis (S1) 2002, Fakultas Seni Pertunjukan ISI Yogyakarta.

Thomas, Karen Kartomi. 2013. "Enchanting the Audience: Dramatic Devices of Sakura Mask Theatre in West Lampung, Sumatra," Asian Theatre Journal, vol 30, no. 2. 